\begin{tabular}{|l|l|l||}
\hline \multicolumn{2}{|c|}{ PublisherInfo } \\
\hline \hline PublisherName & $:$ & BioMed Central \\
\hline \hline PublisherLocation & $:$ & London \\
\hline \hline PublisherImprintName & $:$ & BioMed Central \\
\hline \hline
\end{tabular}

\title{
Chromosome 6 alterations
}

\begin{tabular}{|l|l|l||}
\hline \multicolumn{2}{|c||}{ ArticleInfo } \\
\hline \hline ArticleID & $:$ & 3746 \\
\hline \hline ArticleDOI & $:$ & $10.1186 /$ bcr-2000-66709 \\
\hline ArticleCitationID & $:$ & 66709 \\
\hline ArticleSequenceNumber & $:$ & 18 \\
\hline \hline ArticleCategory & $:$ & Paper Report \\
\hline ArticleFirstPage & $:$ & 1 \\
\hline \hline ArticleLastPage & $:$ & 4 \\
\hline \hline & & RegistrationDate : 2000-5-12 \\
\hline ArticleHistory & $:$ & OnlineDate \\
\hline \hline ArticleCopyright & $:$ & Current Science Ltd2000-5-12 \\
\hline \hline ArticleGrants & $:$ & \\
\hline \hline ArticleContext & $:$ & 1305833 \\
\hline \hline
\end{tabular}




\section{Keywords}

benign breast lesion, chromosome 6q, fibroadenoma, FISH

\section{Introduction}

There is epidemiological evidence to suggest a precursor role for proliferative breast lesions and the subsequent development of breast carcinoma. The presence of genetic abnormalities in these lesions suggests a precursor role, and may shed light on the genetic alterations which may play a part in early breast tumorigenesis. Molecular studies investigating loss of heterozygosity $(\mathrm{LOH})$ on a large series of putative precursor lesions strengthened the concept that hyperplasias may be precursor lesions of breast cancer.

\section{Aims}

To investigate genetic relatedness between putative precursor lesions and breast carcinomas by cytogenetic and molecular cytogenetic methods.

\section{Comments}

Investigations of early premalignant breast lesions are vital both for our understanding of the natural history of the disease and for developing approaches for treatment and prevention. This paper utilizes cytogenetic and molecular cytogenetic approaches to study putative precursor lesions in the breast. The results demonstrate common genetic alterations between these benign lesions and breast cancer, suggesting a common genetic evolution, and also highlight an area of deletion on the long arm of chromosome 6 which may be a significant early event in the development of breast carcinoma.

\section{Methods}


Eighty samples from 72 patients were evaluated, including 31 benign breast tumours (BBT), 14 benign proliferative lesions (BPL) and 35 carcinomas (CA). Cytogenetic analysis was carried out following direct harvesting and short-term incubation of the tumour cells, as well as fluorescent in situhybridization (FISH) using chromosome 6 (a)-satellite and yeast artificial chromosome (YAC) probes.

\section{Results}

In all three groups of lesions, a diploid and haploid chromosome complement was observed, with the haploid cell lines found to be extremely heterogeneous. In the diploid cell lines, monosomies were more frequent than trisomies, with many monosomies (chromosomes 8, 10, 15, 16, 17, 20, 21, 22 and X) common to all three groups. Deletions at $6 \mathrm{q}$ with different breakpoints along the chromosomal arm were the most frequent and the sole common anomaly in all three classes of breast lesion, with a 6q deletion present in 26/31 (84\%) BBT, 9/14 (64\%) BPL and 24/31 (77\%) analyzable CA. In all three classes of lesion, the deletion spanned from 6q23 to 6qter, and the breakpoints most frequently involved in these terminal deletions were $6 \mathrm{q} 24,6 \mathrm{q} 25$ and $6 \mathrm{q} 26$. The minimal common region of deletion was $6 \mathrm{q} 27$ to6qter. FISH studies localized the proximal most commonly involved breakpoint to between 6q24 and $6 q 25$.

\section{Discussion}

Deletions in 6q were by far the most common abnormalities detected in this series of BPL, BBT and CA. As 6q alterations are a frequent finding among breast carcinomas and other solid and haematological malignancies, it is supposed that the development of these lesions involves the same or similar genetic pathways. This is supported by the finding, in the same breast, of coexisting histologically different lesions showing $6 \mathrm{q}$ deletion as the common shared abnormality.

\section{References}


1. Tibiletti MG, Sessa F, Bernasconi B, Cerutti R, Broggi B, Furlan D, Acquati F, Bianchi M, Russo A, Capella C, Taramelli R: A large 6q deletion is a common cytogenetic alteration in fibroadenomas, premalignant lesions. Clin Cancer Res. 2000, 6: 1422-1431. 